\title{
A remarkable illaenid trilobite from the Middle Ordovician of Morocco
}

\author{
ISABEL RÁBANo, JuAN C. GUtiÉRREZ-MARCO \& Diego C. GARCíA-BELLIDO
}

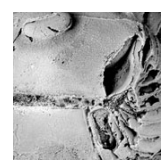

\begin{abstract}
Illaenid trilobites were relatively scarce in south-polar peri-Gondwanan areas during the Ordovician, with all their African occurrences restricted to the Middle and Upper Ordovician of Morocco. At a specific level, only the Bohemian form Ectillaenus benignensis (Novák) has been positively identified from the Middle Ordovician of that region. In the present work we add the discovery of the new form Caudillaenus nicolasi gen. et sp. nov., occurring in a single bed of late Darriwilian 2 age within the Taddrist Formation of the Rahiat region (south of Alnif), in the central Moroccan Anti-Atlas. The new genus is characterized by a large and subtriangular pygidium, a cephalon with relatively large eyes, a broad rostral plate with a short upwardly and forwardly turned posterior flange, and a globose hypostome. It shows a spheroidal enrolment type previously unknown in illaenids, with the pygidium protruding beyond the cephalon, and the cephalic margin fitting into a shallow and wide coaptative furrow on the pygidial doublure. $\bullet$ Key words: Trilobites, Illaenina, enrolment, Ordovician, Gondwana, Anti-Atlas, Morocco.
\end{abstract}

RÁbANO, I., GutiérReZ-MARCO, J.C. \& GARCÍA-Bellido, D.C. 2014. A remarkable illaenid trilobite from the Middle Ordovician of Morocco. Bulletin of Geosciences 89(2), 365-374 (4 figures). Czech Geological Survey, Prague. ISSN 1214-1119. Manuscript received July 10, 2013; accepted in revised form March 19, 2014; published online March 28, 2014; issued May 19, 2014.

Isabel Rábano (corresponding author), Museo Geominero, IGME, Ríos Rosas 23, 28003 Madrid, Spain; i.rabano@igme.es・Juan Carlos Gutiérrez-Marco, Instituto de Geociencias (CSIC, UCM), Facultad CC. Geológicas, José Antonio Novais 12, 28040 Madrid, Spain; jcgrapto@ucm.es•Diego C. García-Bellido, The Environment Institute, Department of Earth and Environmental Sciences, University of Adelaide, South Australia 5005, Australia; Diego.Garcia-Bellido@adelaide.edu.au

Illaenid trilobites are scarce among the Middle and Upper Ordovician assemblages in the African continent, where they have been recorded only from Morocco and are poorly studied. The first mention of an illaenid trilobite from this country was the report of Illaenus by Dubois (in Moret 1933) from the Imini Inlier on the southern slope of the central High Atlas, later revised by Neltner (1938, p. 163) as Illaenus cf. perovalis Murchison. The material comes from Llanvirn shales, perhaps equivalent to the upper part of the Tachilla Formation of the Anti-Atlas, as pointed out by Destombes (1963).

Termier \& Termier (1950) provided the first illustrations of Moroccan illaenids, collected by L. Clariond and other French geologists in Llandeilo and Caradoc beds of the Anti-Atlas. The material consisted of at least seven specimens, originally identified as Illaenus perovalis Murchison (Termier \& Termier 1950, pl. 193, figs 15-17), Illaenus sp. (Termier \& Termier 1950, pl. 193, fig. 23), and Illaenus zeidleri Barrande (Termier \& Termier 1950, pl. 193, figs 18-22). Based on their illustrations, it is difficult to say whether the first illaenid belongs to Ectillaenus perovalis (Murchison, 1839) or even to the similar coarsely ornamented species E. benignensis (Novák, 1918), also recorded from Morocco (see below). The second Moroccan form (Illaenus sp. of Termier \& Termier 1950) is represented by a single cranidium with a broad, barrel-shaped glabella and large eyes, and most likely belongs to Panderia Volborth, 1863 (Gutiérrez-Marco et al. 2003, p. 167). With regards to the third Moroccan representative, originally assigned to the type species of Zdicella Šnajdr, 1957 (= Delgadoa Thadeu, 1947; see Gutiérrez-Marco \& Rábano 1987, p. 663), it seems to be an oculate form and therefore does not belong to that genus.

During detailed field work on the Ordovician formations of Morocco over about 40 years, the French geologist and palaeontologist Jacques Destombes discovered about 50 localities yielding illaenid trilobites, most of them in the Anti-Atlas and situated in the Tachilla Formation (early to middle Darriwilian), the Taddrist, Guezzart and OuineInirne formations of the First Bani Group (late middle Darriwilian to earliest Sandbian), the entire Ktaoua Goup (Sandbian to Katian) and the Lower Second Bani Formation (late Katian to early Hirnantian). However, the published lists of trilobites mention only "illaenids" or 


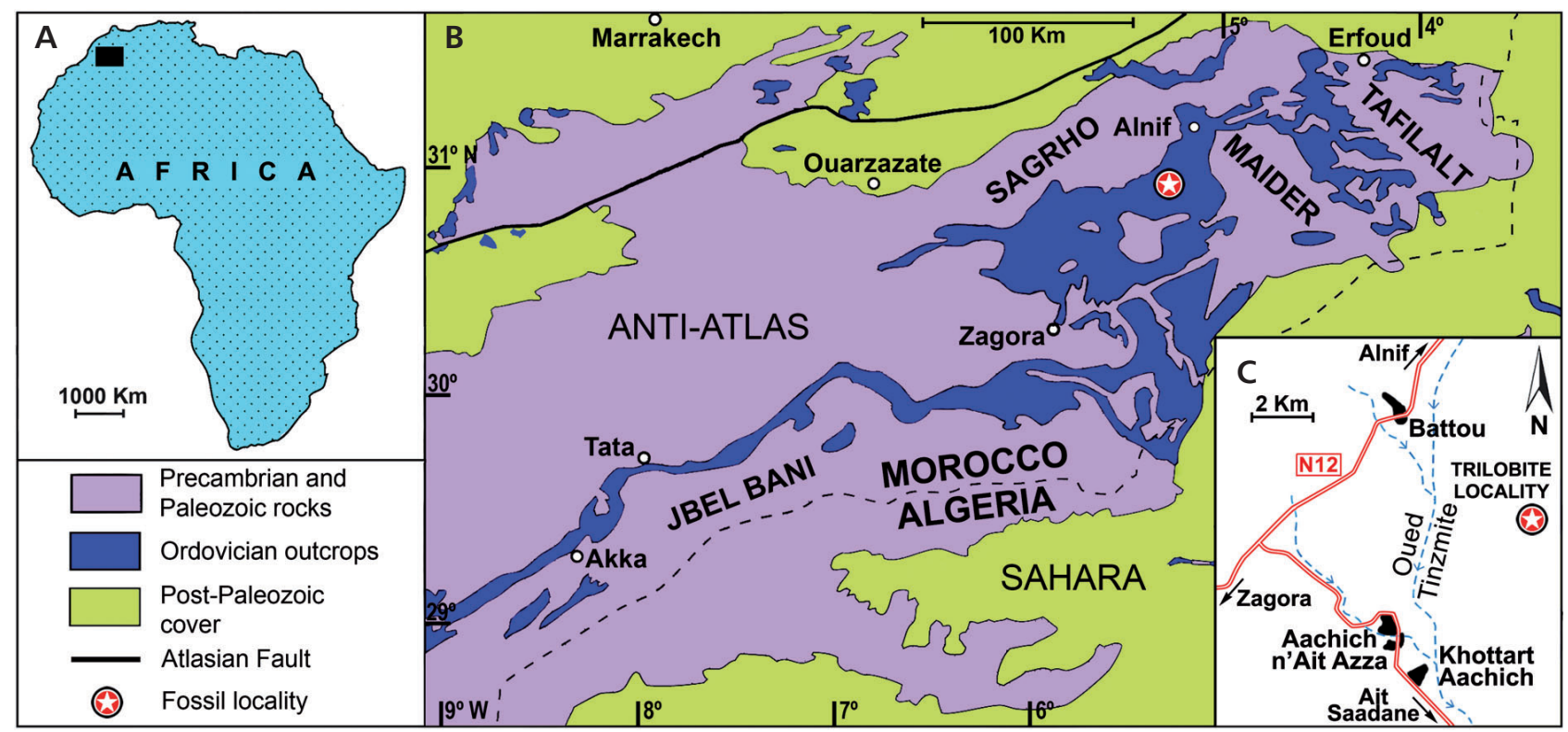

Figure 1. A - map indicating the position of the studied region in Africa. $\bullet$ B - geological sketch map of the central and eastern Anti-Atlas of Morocco (modified from Gutiérrez-Marco et al. 2003), showing the position of the fossil locality (star). $\bullet \mathrm{C}-$ sketch map of the area around the new trilobite site.

"Illaenidae" from most of these localities, except for Ectillaenus sp. and Dysplanus? sp. recorded in the Tachilla, Guezzart and Ouine-Inirne formations (see Gutiérrez-Marco et al. 2003 for compilation of previous data), and Octillaenus sp. in the Upper Ktaoua Formation (Destombes in Destombes et al. 1985, Destombes 2000 and references therein). Outside the Anti-Atlas, a few other unidentified illaenid remains have been cited from Middle and Upper Ordovician formations of the central and eastern High Atlas, as well as in the Coastal Meseta east of Casablanca (Destombes in Destombes et al. 1985, with earlier references).

The most recent report of illaenid trilobites from the Anti-Atlas was by Rábano et al. (2010), who documented the first Moroccan record of the Bohemian species Ectillaenus benignensis (Novák, 1918) from two localities of late Darriwilian age in the Guezzart and Ouine-Inirne formations of the First Bani Group, reinforcing the palaeobiogeographical relationships between Bohemia and Morocco across the peri-Gondwanan platform.

From 2009, a few specimens of a previously unknown illaenid genus from Morocco began to appear at fossil and mineral shows and shops, later being offered on the Internet by fossil traders worldwide. This new illaenid was briefly examined by Rábano et al. (2012), who believed that it derived from Upper Ordovician rocks owing to its purported association, according to a Moroccan dealer, with a cyrtolitid tergomyan mollusc characteristic of the Lower Ktaoua Formation (Katian). Recent field work by the second author in Morocco led to the identification of the exact provenance of this particular trilobite, formally described here as a new genus and species of the family Illaenidae, and which comes from Middle rather than Upper Ordovician beds.

\section{Geological setting}

The studied fossils come from a previously unknown locality in the central Anti-Atlas of Morocco (Fig. 1B), intensively quarried in the last few years by local inhabitants for commercial exploitation of Ordovician trilobites and echinoderms. The site lies $5.8 \mathrm{~km}$ northeast from the town of Aachich n'Ait Azza (Fig. 1C), in the region of Rahiat (= Rihyate). Geographic coordinates for the main trench (Fig. 2) are Lat. $30^{\circ} 55^{\prime} 18^{\prime \prime} \mathrm{N}$, Long. $05^{\circ} 14^{\prime} 51^{\prime \prime} \mathrm{W}$, situated on the Tarhbalt sheet of the 1:50,000 scale topographic map of Morocco (Todrha-Maïder geological map at 1:200,000 scale; Service Géologique du Maroc, Rabat 1988). The fossiliferous bed is restricted stratigraphically to a 40-60 cm-thick interval within a succession of silty shales with decalcified nodules towards the middle part of the Taddrist Formation, the lowermost unit of the First Bani Group, which in this area rests slightly unconformably on shales of the Tachilla Formation. The base of the Taddrist Formation at the studied locality is formed by the so-called Imi-n'Tourza oolitic ironstone bed, still under exploitation in a mine approximately $1 \mathrm{~km}$ east of the fossil locality. The fossiliferous horizon lies about 38-40 m above the top of this widespread ironstone.

A preliminary faunal list from the locality includes, besides the new illaenid Caudillaenus nicolasi gen. et sp. nov., 

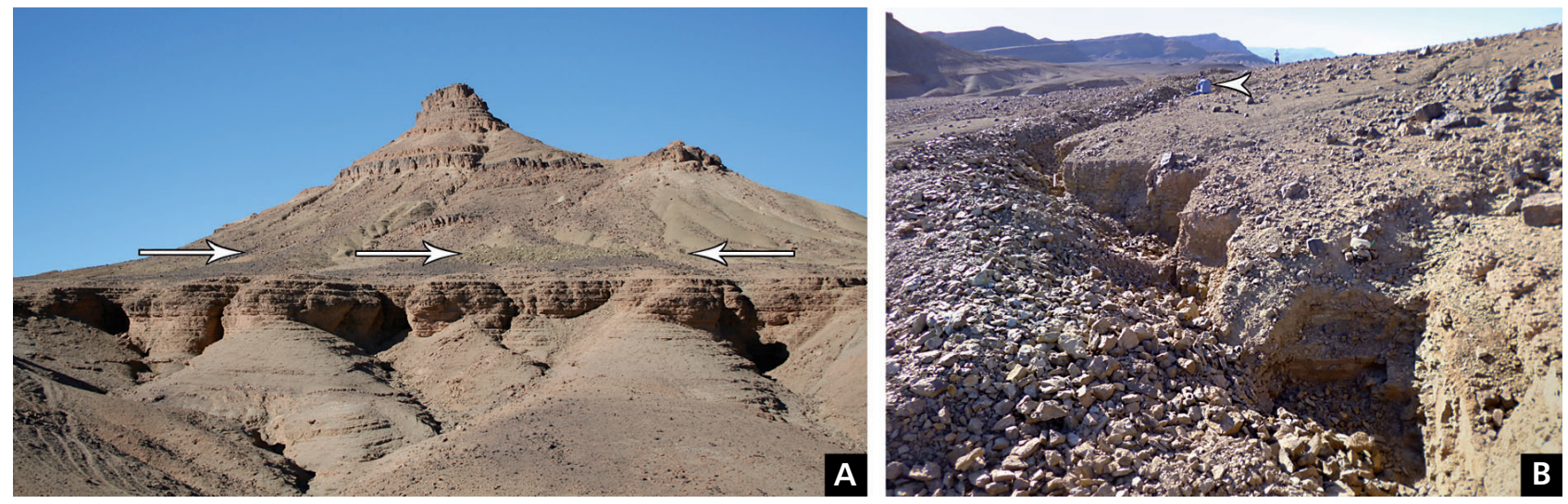

Figure 2. Field views of the fossil locality. $\bullet$ A - fossiliferous bed (arrowed) near the middle part of the Taddrist Formation. $\bullet$ B - detail of trench excavated along the same bed by local inhabitants for commercial prospecting for trilobites and echinoderms; two persons (arrowed and on the skyline) give the approximate scale.

other trilobites such as Morgatia? rochi (Destombes, 1972), Placoparia (Coplacoparia) sp. nov., Colpocoryphe sp., Parabarrandia aff. crassa (Barrande, 1872) and an undetermined cheirurid (Eccoptochile? sp.). The non-trilobite fossils are represented by some molluscs (a cyrtonellid tergomyan, bivalves such as Praenucula sp., orthoconic nautiloids), hyoliths (Elegantilites sp.), echinoderms (Diploporita and Asterozoa indet.), conularids (Exосопиlaria sp.) and rare graptolites (Didymograptus sp.). The sandy shales above and below the fossiliferous bed contain abundant trace fossils such as Teichichnus isp. and Palaeophycus isp. Many of the trilobite specimens found in nodules are articulated, outstretched carapaces and complete exuviae, together with numerous enrolled specimens of Caudillaenus gen. nov. and Parabarrandia aff. crassa that are commonly isolated in the silty shales owing to episodes of rapid burial that also prevented the disarticulation of some starfishes recovered in the nodules.

The Taddrist Formation and the other units included in the First Bani Group of the central Anti-Atlas have traditionally been dated as "Llandeilo sensu lato" (Destombes 1971, Destombes et al. 1985). A later review based on data obtained during completion of the Anti-Atlas geological maps at 1:200,000 scale placed the boundary between the Middle and Upper Ordovician towards the top of this group, whereas the boundary between the traditional "Llanvirn" and "Llandeilo" series was moved up to the middle part of the Bou-Zeroual Formation above the Taddrist Formation. Gutiérrez-Marco et al. (2003) assigned the Taddrist Formation to the upper Oretanian, a regional stage division that is roughly equivalent to the upper Darriwilian 2/basal Darriwilian 3 of the global scale (Gutiérrez-Marco et al. 2008, Bergström et al. 2009). Some of the taxa occurring with Caudillaenus nicolasi at its type locality allow precise dating: the trilobite Morgatia? rochi (Destombes) is restricted to the Didymograptus murchisoni graptolite biozone (Gutiérrez-Marco et al. 2003), and the occurrence of Didymograptus itself (a form with a slender pendent rhabdosome) in a nodule from the same bed reinforces this correlation.

\section{Systematic palaeontology}

Figured and cited specimens are housed in the Museo Geominero of Madrid, Spain (MGM), except one specimen (Fig. 3D, E) which remains in the private collection of $\mathrm{Mr}$ Nicolás Mesas (Cadrete, Spain). Over a hundred additional specimens of Caudillaenus nicolasi have been examined, including specimens in various Moroccan shops, and international fossil shows and websites.

Order Corynexochida Kobayashi, 1935

Suborder Illaenina Jaanusson, 1959

Superfamily Illaenoidea Hawle \& Corda, 1847

Family Illaenidae Hawle \& Corda, 1847

\section{Genus Caudillaenus gen. nov.}

Type species. - Caudillaenus nicolasi gen. et sp. nov., from the Taddrist Formation (upper Oretanian regional stage, in beds equivalent to upper Darriwilian 2 global substage) of the Moroccan Anti-Atlas.

Etymology. - The name refers to the pygidium (L. cauda, tail), which has a unique morphology among illaenid genera, thus the suffix -illaenus.

Diagnosis. - Cephalon parabolic in outline, with moderately large eyes situated about 1.5 times their own length from posterior margin; glabella wide, about half the width of cephalon posteriorly, axial furrows subparallel to slightly curved inwards in vicinity of the lunette ( $c a$ opposite posterior end of the palpebral lobes), genal angles 
rounded. Librigenae with weak subocular furrow. Rostral plate broad (tr.), weakly convex (sag.), posterolaterally defined by almost transverse connective sutures and with a short upwardly and forwardly turned flange on the posterior edge. Hypostome with a narrow and globose middle body. Thorax of ten segments with well-defined axis that is broader than pleurae in dorsal view; axial furrows subparallel; pleurae adaxial to fulcrum successively increasing in width (tr.) posteriorly. Pygidium subtriangular in outline, larger than cephalon; axis weakly defined, subconical; pleural region concave posteromedially. Pygidial doublure broad, divided into convex outer half and flattened or weakly concave inner half by a shallow vincular furrow running approximately parallel to the inner margin. Dorsal surface of carapace almost smooth, with sculpture of fine terrace lines and small pits only developed on the anteriormost part of cephalon and the lateral borders of pygidium.

Remarks. - With the exception of some Silurian and Devonian scutelluids, typical illaenimorph trilobites have a pygidium that is semicircular to parabolic in outline. The pygidium of Caudillaenus is unique among illaenid trilobites in shape and in the presence of a vincular furrow. However, the cephalic and thoracic morphology is rather conservative, with the exception of the rostral plate which is somewhat reminiscent of that of some Cybantyx, Liolalax and Bumastus? species (Lane \& Thomas 1978, 1983; Holloway \& Lane 1998) in its almost triangular shape in ventral view. However, the rostral plates of those genera differ from that of Caudillaenus in that the connective sutures are oblique rather than almost transverse and approach the midline posteriorly.

The spheroidal mode of enrolment of Caudillaenus nicolasi, with the posterior end of the pygidium projecting beyond the glabella, resembles the "pseudomegalaspis type" of Harrington (1959, fig. 75A, p. O104). However, in Pseudomegalaspis Jaanusson, 1953 the anterior margin of the cephalon fits against the inner edge of the pygidial doublure on enrolment, whereas in C. nicolasi the anterior margin of the cephalon abuts the middle (sag., tr.) of the pygidial doublure, fitting into the shallow vincular furrow that serves to stabilize the enrolment (Figs 3K, 4H-L). A different kind of closing mechanism resulting in the projection of the pygidium beyond the cephalon was developed in an apomorphic group of Devonian homalonotids that includes Digonus Gürich, 1909, but in this case a pointed process on the rostral plate fits against the inner edge of the pygidial doublure (Wenndorf 1990, fig. 13). The enrolment mode of $C$. nicolasi should not be confused, either, with the taphonomic effect resulting in the so-called "discoidal hyper-enrolment type" described by Pillet (1982), where compactional flattening of specimens of Ectillaenus with a normal spheroidal enrolment of the "asaphid type", with the cephalic and pygidial doublures facing each other (see Harrington 1959, fig. 75B, p. O104), has caused the pygidium and thorax to be displaced posteriorly, so that the pygidium projects beyond the front of the cephalon.

Occurrence. - As for type and only known species.

Caudillaenus nicolasi sp. nov.

Figures 3, 4

2012 Caudillaenus nicolasi gen. et sp. nov. (nomina nuda); Rábano et al., p. 49.

2012 Illaenidae nov.?; Lebrun, p. 9 (photograph).

Etymology. - After Mr Nicolás Mesas (Cadrete, Spain), who provided us with the first specimens of this trilobite, making them available for study.

Holotype. - MGM 6729X, internal mould of a complete, undeformed, well-preserved, enrolled specimen (Fig. 3G-K).

Type locality and horizon. - Trench excavated in 2014 (Fig. 2) at an unnamed site in the Rahiat region of the central Moroccan Anti-Atlas, $5.8 \mathrm{~km}$ northeast of Aachich n'Ait Azza (Lat. $30^{\circ} 55^{\prime} 18^{\prime \prime} \mathrm{N}$, Long. 05 14' 51"W). The fossiliferous bed occurs towards the middle of the Taddrist Formation, about $38-40 \mathrm{~m}$ above the top of the Imi-n'Tourza oolitic ironstone bed that constitutes the base of this lithostratigraphic unit. Late Oretanian (= late Darriwilian 2) in age.

Paratypes. - A complete, outstretched carapace (MGM 6731X; Fig. 3A-C, F); three enrolled specimens (MGM 6730X, Fig. 4H-L; MGM 6919X, not figured; MGM 6920X, with eroded dorsal surface of cephalon, Fig. 4B, C); a complete cephalon (MGM 6921X, Fig. 4A, D, E); seven pygidia (MGM 6922X, internal mould with fragment of external mould, Fig. 4N; MGM 6923X, fragment of external + internal mould, Fig. 4O, P; MGM 6924X, internal

Figure 3. Caudillaenus nicolasi gen. et sp. nov., Taddrist Formation (Middle Ordovician), Morocco. • A-C, F-paratype, MGM 6731X, internal mould of dorsal exoskeleton; A, B - dorsal and lateral views, $\times 1.3 ; \mathrm{C}$ - detail of the last thoracic segments and the pygidium in slightly oblique posterior view, $\times 1.5 ; \mathrm{F}$ - dorsal view of cephalon, $\times 1.8 . \cdot \mathrm{D}, \mathrm{E}-$ cephalon of a complete specimen in anterior and right-lateral views, $\times 0.9$ and $\times 1.3$ respectively; original in the private collection of Mr Nicolás Mesas. $-\mathrm{G}-\mathrm{K}$ - holotype, MGM 6729X, enrolled dorsal exoskeleton; G - cephalon in dorsal view, $\times 1.4$; $\mathrm{H}$ - pygidium in dorsal view, $\times 1.3$; I - pygidium in lateral view, $\times 1.4$; $\mathrm{J}$ - detail of left eye, $\times 4$; $\mathrm{K}-$ specimen in lateral view, $\times 1.4$. 

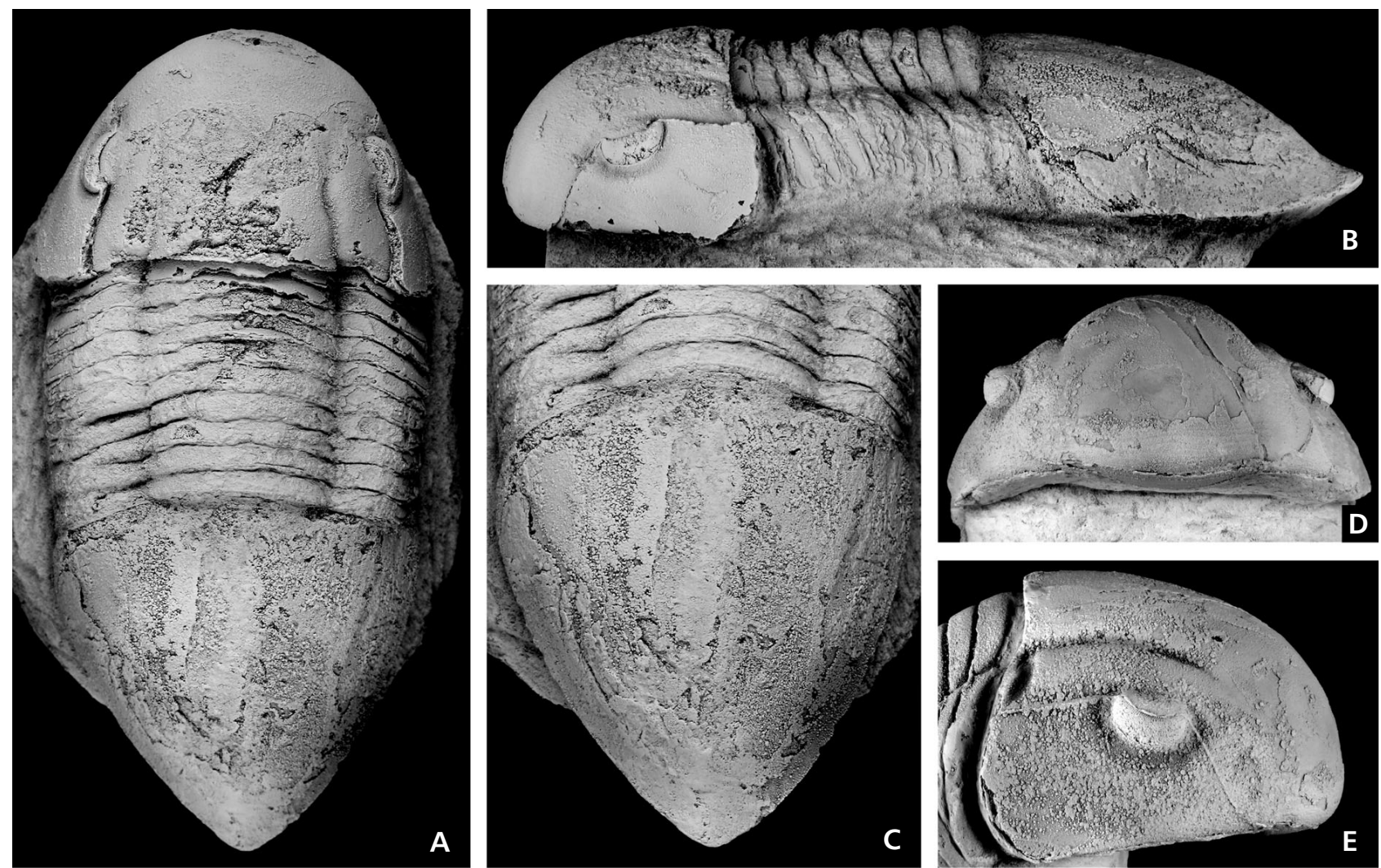

A
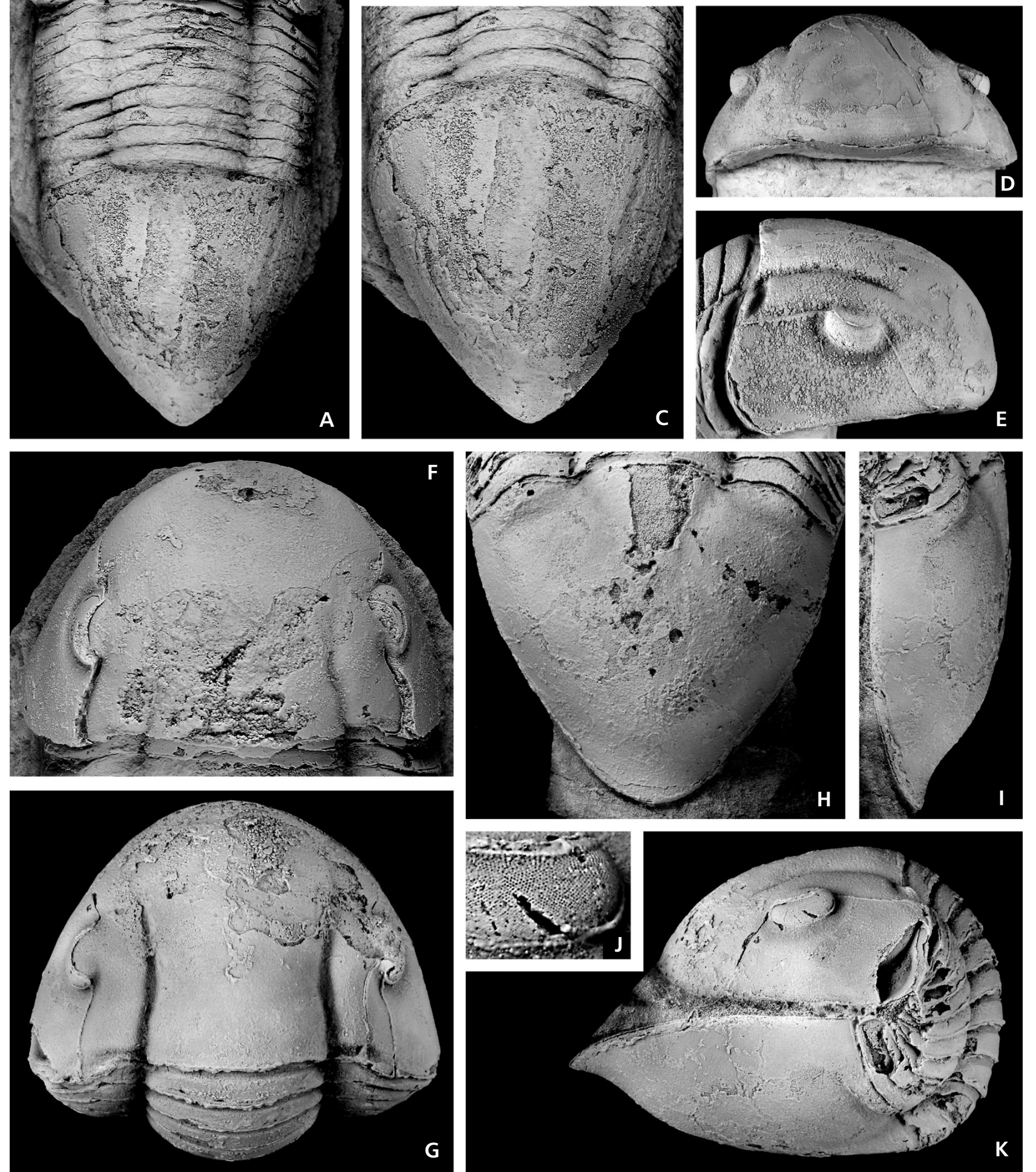
mould with detached doublure, not figured; MGM 6925X, internal mould with well-preserved doublure, not figured; MGM 6926X, Fig. 4F, G; MGM 6927X, fragment of external mould, not figured; MGM 6928X, fragment of internal + external mould, not figured); and a left librigena (MGM 6929X, external mould). All from the type locality.

Other material. - A complete and partially enrolled specimen (Fig. 3D, E) from the type locality is in the private collection of Mr Nicolás Mesas.

Diagnosis. - As for the genus.

Description. - Cephalon vaulted, slightly more convex transversely than sagittally; sagittal length 25-41 mm, 83-90\% of maximum width. Glabella clearly defined only in posterior half of cranidium, comprising 58-64\% of cranidial width at posterior margin and $45-50 \%$ of the maximum cephalic width. Axial furrows gently diverging anteriorly and posteriorly from lunette. Fixigenae elongated, subrectangular in posterior half of cephalon where it can be distinguished from the glabella, width at posterior margin approximately one-third of the glabellar width. Palpebral lobes large, arched, almost flat in lateral view, with anterior edges situated just in front of cephalic mid-length (sag.) in dorsal view, their length (exsag.) corresponding to 17-20\% of cephalic length. Palpebral furrows faint, most distinct posteriorly. Preocular sutures diverging slightly forwards immediately in front of eyes before converging in a broad curve and joining under the anterior edge of the cephalon. Postocular sutures weakly sigmoidal and slightly diverging overall, intersecting the posterior margin of cephalon in line (exsag.) with outer edge of palpebral lobes and at an angle of about $70-75^{\circ}$. A faint posterior furrow, subparallel to the posterior edge of the fixigena, dies out before reaching the facial suture. Librigenae smooth, broader than fixigenae in lateral view, extending slightly farther back than the posterior extremity of cranidium. Visual surface arched (vertical and exsag.) and kidney-shaped, about three times longer than high and covered with numerous very tiny holochroal lenses, bounded below by a broad and shallow subocular furrow that is slightly deeper and wider posteriorly than anteriorly. Doublure of librigenae narrow, with a sharp ridge posteriorly, subparallel to the posterior edge of the cephalon. Rostral plate weakly convex (sag.), broad (tr.), of wide subtriangular outline (Fig. 4A), laterally defined by almost straight connective sutures forming an angle of convergence of $170^{\circ}$. Posterior margin of rostral plate slightly pointed backwards in ventral view, with a short upwardly and forwardly turned flange. General outline of the hypostome unknown, but with a narrow and globose middle body. Its anterior margin must have had a median indentation into which the rostral flange fitted.

Thorax with ten segments. Pleural regions moderately arched (tr.). Pleural tips obtuse, with doublure increasing in width (tr.) on more posterior segments. A single apodeme is present on the posterior part of all the thoracic segments beneath the axial furrows (Fig. $3 \mathrm{H}$ ).

Pygidium with axis comprising about $39-45 \%$ of maximum pygidial width, with an observed maximum width of $63 \mathrm{~mm}$. Axis short, about 23-30\% of the sagittal pygidial length in dorsal view; axial furrows almost completely effaced, even less indistinct posteriorly than anteriorly, better defined on internal than external surface. Pleural areas without traces of segmentation except for first pair of pleural furrows that are very shallow and wide (exsag.), run obliquely backwards, and become indistinct distally. Posterior and lateral pleural margins forming sharp edge with doublure. Doublure comprising about $38-40 \%$ of the pygidial length sagittally and tapering anteriorly; inner margin with wide, gentle, forwardly-curved deflection medially. In longitudinal section, doublure sigmoidal with broad, weakly concave anterior part and convex marginal part separated by shallow vincular furrow. This furrow weakens on anterior and posteromedian part of the doublure.

Dorsal surface of the cephalon is virtually smooth apart from some very fine, long and transverse terrace ridges on the front of the cranidium, not extending laterally onto the librigenae. Rostral plate with sculpture of about seven long, unbranched, relatively faint terrace ridges, running continuously between connective sutures and mainly subparallel to anterior margin of rostral plate. Sculpture on dorsal surface of the pygidium is most pronounced in the

Figure 4. Caudillaenus nicolasi gen. et sp. nov., Taddrist Formation (Middle Ordovician), Morocco. • A, D, E - paratype, MGM 6921X, internal mould of cephalon showing ventral details $(\mathrm{A}, \times 1.2)$, and aspects of right and left eyes ( $\mathrm{D}$ and E respectively, $\times 3.8)$, including the weak subocular furrow on librigenae. $\bullet \mathrm{B}, \mathrm{C}$ - paratype, MGM 6920X, latex cast of anterior part of cephalon of an eroded specimen showing details of rostral plate, connective sutures and hypostome in ventral $(\mathrm{B}, \times 1.4)$ and posteroventral $(\mathrm{C}, \times 1.1)$ views. $\bullet \mathrm{F}, \mathrm{G}-$ paratype, MGM 6926X, internal mould of pygidium in dorsal $(\mathrm{F}, \times 0.9)$ and posterior $(\mathrm{G}, \times 1)$ views. $\bullet \mathrm{H}-\mathrm{L}$ - paratype, MGM $6730 \mathrm{X}$, internal mould of enrolled dorsal exoskeleton prepared to show external mould of pygidial doublure; $\mathrm{H}-\mathrm{J}$ - pygidium in lateral, dorsal and oblique posterior views, showing the shape of the broad coaptative furrow on the doublure, $\times 1.2$, $\times 1.2$ and $\times 1$, respectively; $\mathrm{K}$ - complete specimen in lateral view, $\times 0.4 ; \mathrm{L}$ - detail of $\mathrm{H}$ (rotated $90^{\circ} \mathrm{CCW}$, showing interfingering, outward branching and diverging terrace ridges), $\times 1.4$. $\bullet$ M - paratype, MGM 6924X, right anterolateral corner of an isolated pygidium, preserved as a natural external mould, showing terrace ridges and fine pits, $\times 2.5 . \bullet \mathrm{N}$ - paratype, MGM 6922X, latex cast of right anterolateral corner of pygidium showing fine pits and larger, randomly arranged pits, $\times 2.8 . \bullet \mathrm{O}, \mathrm{P}-$ paratype, MGM $6923 \mathrm{X}$, latex cast of right anterolateral corner of pygidium, showing the faint sculpture $(\mathrm{O}, \times 2.5)$ and detail of the lower part of the area $(\mathrm{P}, \times 4.1)$. 
Isabel Rábano et al. • A remarkable illaenid trilobite from the Middle Ordovician of Morocco
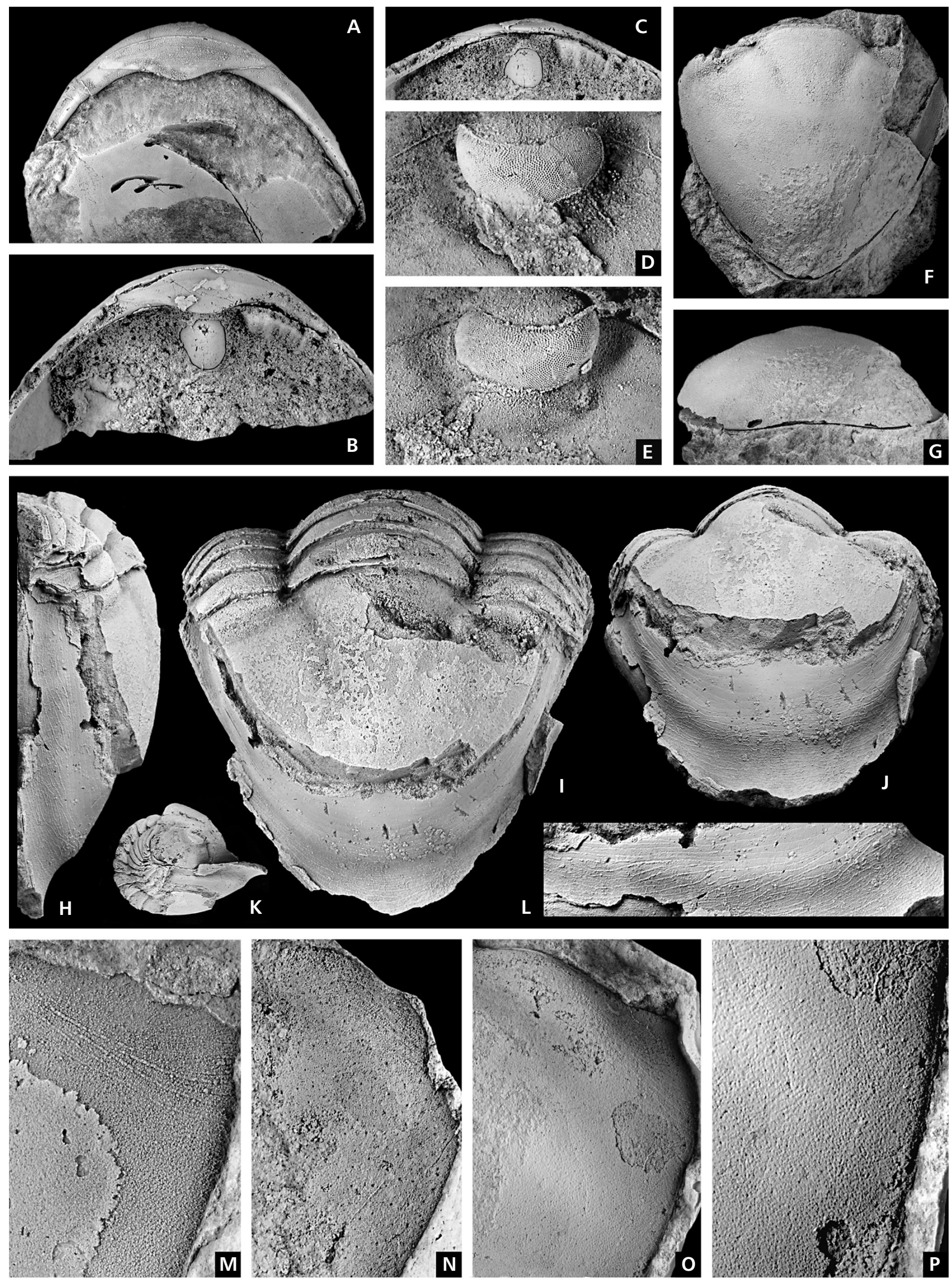
anterolateral corners, where a few terrace ridges curve towards the articulating facet. Close to the pygidial margin there are lineations of minute pores, aligned obliquely to the margin, among which a few slightly larger-diameter pits are randomly arranged. Pygidial doublure with fine terrace ridges running subparallel to anterior and posterior margins, more dense on outer than inner part of doublure, and interfingering medially in vincular furrow where they are more oblique to pygidial margin.

Occurrence. - Caudillaenus nicolasi gen. et sp. nov. is known from a single locality in the Rahiat region (south of Alnif) of the central Moroccan Anti-Atlas, within the middle part of the Taddrist Formation, First Bani Group, and from beds of late Oretanian age (= late Darriwilian 2 of the global scale).

\section{Conclusions}

Illaenid trilobites are apparently rare and of limited diversity in the Ordovician of Morocco, in comparison with the up to 10 genera and 27 species so far recorded from Sandbian-Katian strata of the three areas that share diverse trilobite species in common with Morocco across the peri-Gondwanan realm (Gutiérrez-Marco et al. 1999): the Prague Basin (Šnajdr 1957, Bruthansová 2003), Ibero-Armorica (Kerforne 1900; Thadeu 1947; Hammann 1976, 1992) and Sardinia (Hammann \& Leone 1997). In Middle Ordovician strata, illaenids are represented by two genera and six species in Bohemia (Šnajdr 1957, Bruthansová 2003) and two genera and species in Ibero-Armorica (Rábano \& Gutiérrez-Marco 1983, Rábano 1989 with earlier references, Lebrun 2002). In coeval beds in the Moroccan Anti-Atlas illaenid diversity is greater than in the Upper Ordovician and includes, apart from the new taxon Caudillaenus nicolasi in the Taddrist Formation, Ectillaenus sp. and Dysplanus? sp. in the Tachilla Formation and some beds of the First Bani Group (references in Gutiérrez-Marco et al. 2003), the "Bohemian" form Ectillaenus benignensis (Novák, 1918) in the Guezzart and Ouine-Inirne formations (Rábano et al. 2010), and the preliminary identification of the "southwestern-European" species Ectillaenus giganteus (Burmeister, 1843) and Panderia beaumonti (Rouault, 1847) from the Tachilla and Guezzart formations by the present authors (unpublished data). The record of $C$. nicolasi adds a new and important element to the palaeobiogeographical knowledge of Ordovician trilobite assemblages from the peri-Gondwanan African margin, and fits well in the so-called "Calymenacean-Dalmanitacean" cratonic fauna (Cocks \& Fortey 1990), represented by particular inshore trilobite biofacies developed in southernmost Gondwanan palaeolatitudes and very rich in endemic forms.
From both functional morphological and palaeontological perspectives, the unusual enrolment mode of Caudillaenus nicolasi involves a closing mechanism that has not been recorded previously in illaenid trilobites, in which the posterior end of the pygidium projects beyond the front of the cephalon, with the anterior and lateral margins of the cephalon fitting into a shallow and wide coaptative furrow on the pygidial doublure.

\section{Acknowledgements}

We thank David J. Holloway (Museum Victoria, Australia) and Philip D. Lane (Keele University, United Kingdom), for their detailed and constructive criticism of this paper. We are also grateful to Nicolás Mesas Sánchez (Cadrete, Spain) for making the first specimens of Caudillaenus nicolasi available for study; to Julio Martín Sánchez (Madrid, Spain), Julio Cabo (Navas de Estena, Spain) and Enrique Bernárdez (Atacama University, Chile) for their help during fieldwork; and to Carlos Alonso (Complutense University of Madrid, Spain) for photography. This is a contribution to project CGL2012-39471 of the Spanish Ministry of Economy and Competitiveness, and to the International Geoscience Programme (IGCP) Project 591 - The Early to Middle Paleozoic Revolution (IUGS-UNESCO).

\section{References}

BARRANDE, J. 1872. Systême silurien du centre de la Bohême. lère partie: Recherches paléontologiques. Supplément au Vol. I. Trilobites, crustacés divers et poissons. $647 \mathrm{pp}$. Chez l'auteur et éditeur, Imprimerie de Charles Bellmann, Prague.

Bergström, S.M., Chen, X., Gutiérrez-Marco, J.C. \& Dronov, A.V. 2009. The new chronostratigraphic classification of the Ordovician System and its relations to major regional series and stages and $\delta^{13} \mathrm{C}$ chemostratigraphy. Lethaia 42(1), 97-107. DOI 10.1111/j.1502-3931.2008.00136.x

BruthansovÁ, J. 2003. The trilobite family Illaenidae Hawle et Corda, 1847 from the Ordovician of the Prague Basin (Czech Republic). Transactions of the Royal Society of Edinburgh, Earth Sciences 93, 167-190.

BurmeIster, H. 1843. Die Organisation der Trilobiten, aus ihren lebenden Verwandten entwickelt; nebst einer systematische Uebersicht aller zeither beschriebenen Arten. 147 pp. Reimer, Berlin. DOI 10.5962/bhl.title.9086

Cocks, L.R.M. \& ForTeY, R.A. 1990. Biogeography of Ordovician and Silurian faunas, 97-104. In McKerrow, W.S. \& Scotese, C.R. (eds) Palaeozoic Palaeogeography and Biogeography. Geological Society of London Memoir 12.

Destombes, J. 1963. Le Cambrien et l'Ordovicien de la boutonnière de l'Imini (zone sub-atlasique méridionale, Maroc). Comptes Rendus Sommaire des Séances de la Société géologique de France 1963(7), 231-232.

Destombes, J. 1971. L'Ordovicien au Maroc. Essai de synthèse 
stratigraphique. Mémoires du Bureau des Recherches géologiques et Minières 73, 237-263.

Destombes, J. 1972. Les trilobites du sous-ordre des Phacopina de l'Ordovicien de l'Anti-Atlas (Maroc). Notes et Mémoires du Service géologique du Maroc 32(240), 1-114.

Destombes, J. 2000. Catalogue des macrofaunes recoltées dans l'Ordovicien de l'Anti-Atlas (Maroc). 107 pp. Unpublished report, Pessac.

Destombes, J., Hollard, H. \& Willefert, S. 1985. Lower Palaeozoic rocks of Morocco, 91-336. In Holland, C.H. (ed.) Lower Palaeozoic rocks of the World, vol. 4. Lower Palaeozoic of north-western and west central Africa. John Wiley and Sons, Chichester.

GÜRICH, G. 1909. Leitfossilien. Ein Hilfsbuch zum Bestimmen von Versteinerungen bei geologischen Arbeiten in der Sammlung und im Felde. Zweite Lieferung: Devon, 97-199. Gebrüder Borntraeger, Berlin.

Gutiérrez-Marco, J.C., Destombes, J., Aceñolaza, F.G., SArmiento, G.N., RÁbano, I. \& SAN José, M.A. DE 2003. El Ordovícico Medio del Anti-Atlas marroquí: paleobiodiversidad, actualización bioestratigráfica y correlación. Geobios 36(2), 151-177.

DOI 10.1016/S0016-6995(03)00004-4

GutiérRez-Marco, J.C. \& RÁBAnO, I. 1987. Trilobites y graptolitos de las lumaquelas terminales de los "Bancos Mixtos" (Ordovícico Superior de la zona Centroibérica meridional): Elementos nuevos o poco conocidos. Boletín Geológico y Minero 93, 647-669.

Gutiérrez-Marco, J.C., Rábano, I., Sarmiento, G.N., Aceñolaza, G.F., San José, M.A., Pieren, A.P., Herranz, P., Couto, H.M. \& PiçARrA, J.M. 1999. Faunal dynamics between Iberia and Bohemia during the Oretanian and Dobrotivian (late Middle-earliest Upper Ordovician), and biogeographic relations with Avalonia and Baltica. Acta Universitatis Carolinae, Geologica 43, 487-490.

Gutiérrez-Marco, J.C., SÁ, A.A. \& RÁbano, I. 2008. Ordovician time scale in Iberia: Mediterranean and global correlation, 46-49. In Rozhnov, S.V. (ed.) Proceedings of the International Conference "Development of Early Paleozoic Biodiversity: Role of Biotic and Abiotic Factors, and Event Correlation”, Moscow, Russia, 26-28 June, 2008, Paleontological Institute, Russian Academy of Sciences. Paleontological Journal 43(11). KMK Scientific Press, Moscow.

Hammann, W. 1976. Trilobiten aus dem oberen Caradoc der östlichen Sierra Morena (Spanien). Senckenbergiana lethaea 57(1), 35-85.

HammanN, W. 1992. The Ordovician trilobites from the Iberian Chains in the province of Aragón, NE-Spain. I. The trilobites of the Cystoid Limestone (Ashgill Series). Beringeria 6, $1-219$.

Hammann, W. \& Leone, F. 1997. Trilobites of the post-Sardic (Upper Ordovician) sequence of southern Sardinia. Part I. Beringeria 20, 1-217.

HaRrington, H.J. 1959. General description of Trilobita, O38-O117. In MoORE, R.C. (ed.) Treatise on Invertebrate Paleontology. Part O. Arthropoda 1. Geological Society of America \& University of Kansas Press, Lawrence.
Hawle, I. \& Corda, A.J.C. 1847. Prodrom einer Monographie der böhmischen Trilobiten. 176 pp. J.G. Calve, Prague. [Reprinted in 1848 in Abhandlungen der königlichen böhmischen Gessellschaft der Wissenschaften 5, 117-292.]

Holloway, D.J. \& Lane, P.D. 1998. Effaced styginid trilobites from the Silurian of New South Wales. Palaeontology 41(5), 853-896.

JAANUSSON, V. 1953. Untersuchungen über baltoskandische Asaphiden. I. Revision der mittelordovizischen Asaphiden des Siljan-Gebietes in Dalarna. Arkiv för Mineralogi och Geologi 14, 377-464.

JAAnusson, V. 1959. Family Illaenidae Hawle \& Corda, 1847, 372-376. In Moore, R.C. (ed.) Treatise on Invertebrate Paleontology. Part O. Arthropoda 1. Geological Society of America \& University of Kansas Press, Lawrence.

Kerforne, F. 1900. Description de trois nouveaux trilobites de l'Ordovicien de Bretagne. Bulletin de la Société géologique de France 3(28), 783-791.

Kobayashi, T. 1935. The Cambro-Ordovician formations and faunas of South Chosen. Paleontology, Part III. Cambrian faunas of South Chosen with a special study on the Cambrian trilobite genera and families. Journal of the Faculty of Science, University of Tokyo, Section 2 - Geology, Mineralogy, Geography, Geophysics 4(2), 49-344.

Lane, P.D. \& Thomas, A.T. 1978. Family Scutelluidae, 8-29. In Thomas, A.T. British Wenlock trilobites. Part 1. Monograph of the Palaeontographical Society 131(552), 1-56.

LANe, P.D. \& Thomas, A.T. 1983. A review of the trilobite order Scutelluina. Special Papers in Palaeontology 30, 141-160.

Lebrun, P. 2002. Trilobites de France. Tome 1. Généralités sur les trilobites, Massif armoricain (Bretagne, Normandie, Vendée). Minéraux \& Fossiles, Hors-série 14, 1-132.

LeBrun, P. 2012. "Découvertes paléontologiques": quoi de neuf à Sainte-Marie-aux-Mines 2012? Fossiles 11, 5-18.

Moret, L. 1933. Compléments à la stratigraphie de la zone sub-atlasique méridionale de l'Atlas de Marrakech. Comptes Rendus Sommaire des Séances de la Société géologique de France 1933(16), 257-258.

Murchison, R.I. 1839. The Silurian System, founded on geological researches in the counties of Salop, Hereford, Radnor, Montgomery, Caermarthen, Brecon, Pembroke, Monmouth, Gloucester, Worcester and Stafford; with descriptions of the coal-fields and overlying formations. xxxii $+768 \mathrm{pp}$. John Murray, London.

Neltner, L. 1938. Études géologiques dans le Sud marocain. Notes et Mémoires du Service géologique du Maroc 42, $1-298$.

NovÁK, O.P. 1918. Trilobiti pásma D-d $\mathrm{d}_{1 \gamma} \mathrm{z}$ okolí pražského. Rukopisná studie k tisku upravil a doplňky opatřil Jaroslav Perner. Palaeontographica Bohemiae 9, 1-51.

Pillet, J. 1982. A propos du mode d'enroulement des trilobites. L'hyperenroulement discoïde. Bulletin de la Société d'Etudes scientifiques de l'Anjou [nouvelle série] 11, 135-138.

RÁBAnO, I. 1989. Trilobites del Ordovícico Medio del sector meridional de la Zona Centroibérica española. Parte IV. Phacopina, Scutelluina, Odontopleurida y Lichida. Boletín Geológico y Minero 100(6), 971-1032. 
RÁbANo, I. \& GuTIÉRREZ-MARCO, J.C. 1983. Revisión del género Ectillaenus Salter, 1867 (Trilobita, Illaenina) en el Ordovícico de la Península Ibérica. Boletín de la Real Sociedad Española de Historia Natural (Geología) 81(3-4), 225-246.

Rábano, I., Gutiérrez-Marco, J.C. \& García-Bellido, D.C. 2012. Svobodapeltis and other effaced illaenid trilobites from the Mediterranean Ordovician, 49. In Budil, P. \& FATKA, O. (eds) The $5^{\text {th }}$ Conference on Trilobites and their relatives. Abstracts. 59 pp. Czech Geological Survey \& Charles University, Prague.

Rábano, I., Sá, A.A., Gutiérrez-Marco, J.C. \& García-BelLIDO, D.C. 2010. Two more Bohemian trilobites from the Ordovician of Portugal and Morocco. Bulletin of Geosciences 85(3), 415-424. DOI 10.3140/bull.geosci.1173

Rouault, M. 1847. Extrait du mémoire sur les trilobites du département d'Ille-et-Vilaine. Bulletin de la Société géologique de France 2(4), 309-328.
ŠNAJDR, M. 1957. Klasifikace čeledě Illaenidae (Hawle a Corda) v českém starším paleozoiku. Sborník Ústředního ústavu geologického, Oddíl paleontologický 23, 125-284.

Termier, G. \& Termier, H. 1950. Paléontologie Marocaine. Tome II. Invertébrés de l'Ère Primaire. Fascicule IV. Annélides, Arthropodes, Échinodermes, Conularides et Graptolithes. 279 pp. Hermann \& Cie, Paris.

Thadeu, D. 1947. Trilobites do Silúrico de Loredo (Buçaco). Boletim da Sociedade Geológica de Portugal 6(3), 217-236.

Volborth, A.V. 1863. Über die mit glatten Rumpfgliedern versehenen russischen Trilobiten, nebst einem Anhange über die Bewegunsorgane und über das Herz derselben. Mémoires de l'Academie Impériale des Sciences de St-Petersbourg 7, 6(2), 1-47.

WenNDORF, K.-W. 1990. Homalonotidae (Trilobita) aus dem Rheinischen Unter-Devon. Palaeontographica A 211(1-6), $1-184$. 